\title{
Clinical features, treatments and perinatal outcomes of novel coronavirus infection during pregnancy: a systematic review
}

\author{
Narayana Goruntla, Jyothi Suchitra, Kannan M Shanmugha, Dasaratharamaiah Jinka, \\ Mohammad Jaffar Sadiq, Vigneshwaran Easwaran
}

\begin{abstract}
Corresponding author: Mr. Narayana Goruntla, Assoc. Professor, Dept. of Pharmacy Practice, Raghavendra Institute of Pharmaceutical Education and Research (RIPER), Anantapur, Andhra Pradesh, India; Email : narayanagoruntla@gmail.com
\end{abstract}

Distributed under Attribution-Non Commercial - Share Alike 4.0 International (CC BY-NC-SA 4.0)

\begin{abstract}
Objectives: To collect all studies related to COVID-19 infected pregnant women and summarize the symptoms, laboratory findings, treatments, and perinatal outcomes. Methods: The systematic review was conducted according to the PRISMA consensus statement. A systematic search was performed in PubMed, Scopus, Web of Science, and Cochrane databases on April 3, 2020. All studies relevant to COVID-19 infection among pregnant women are considered for inclusion. A total of 12 studies are considered for inclusion in this systematic review. Two authors extracted the data by using pre-designed, piloted, and customized data extraction form. Results : Fever (60.2\%), cough $(36.6 \%)$, and postpartum fever $(23.5 \%)$ are the most common symptoms observed in pregnant women infected with COVID 19. The most common abnormal laboratory finding observed in COVID 19 infected pregnant women include; raised AST or ALT (21.0\%), lymphopenia (55.8\%), elevated C-reactive protein (62.2\%), and abnormal chest CT scan (90.2\%). Oxygen administration, antibiotic, and antiviral therapy is the mainstay of management strategy in the majority of the studies. Chloroquine and hydroxychloroquine are not advised in pregnancy due to secondary complications. The most common adverse obstetric and neonatal outcomes are preterm delivery, C-section, fetal distress, and low birth weight. There was no vertical transmission of COVID 19 from mother to fetus. Conclusion: Fever, cough, postpartum fever, elevated C-reactive protein, lymphopenia, and abnormal chest CT are the most common clinical and laboratory examinations in pregnant women infected with COVID-19. All healthcare professionals need to consider possible outcomes in this review and make a decision to reduce the risk of complications in both mother and fetus.
\end{abstract}

Keywords: COVID-19, novel Coronavirus, neonatal outcomes, perinatal outcomes, symptoms, lab abnormalities.

On 30th January 2020, the World Health Organization (WHO) declared the novel Coronavirus disease 2019 (COVID-19) as a public health emergency of international concern (PHEIC) after it crosses the number of infected cases beyond 2002-2003 outbreaks of severe acute respiratory syndrome (SARS) in China ${ }^{1,2}$. Since its initial detection in Wuhan, Hubei province, China, COVID-19 has now been reported from all continents except Antarctica, affecting 754,948 people in 202 countries and resulting in 36,571 deaths as of April 1, 2020. On March 11, the World Health Organization (WHO) officially changed its taxonomy of the situation from a public health emergency of

Received: $21^{\text {st }}$ January 2021, Peer review completed: $24^{\text {th }}$ February 2021, Accepted: $7^{\text {th }}$ March 2021.

Goruntla N, Suchitra J, Shanmugha KM, Jinka D, Sadiq MJ, Easwaran V. Clinical features, treatments and perinatal outcomes of novel coronavirus infection during pregnancy: a systematic review. The New Indian Journal of OBGYN. 2021; 8(1): 7-13. 
international concern to a pandemic ${ }^{3}$.

Evidence shows that, Corona family members lead to severe acute respiratory syndrome coronavirus (SARS-CoV) and the Middle East respiratory syndrome coronavirus (MERS-CoV) can cause severe complications during pregnancy. A study conducted by Wong SF et al on outcomes of SARS-CoV infection in 12 pregnant women revealed, seven women had a miscarriage in $1^{\text {st }}$ trimester, two of five women had fetal growth retardation in $2^{\text {nd }}$ to $3^{\text {rd }}$ trimester, four of five women had a preterm delivery, and three women died during pregnancy period ${ }^{4}$. Similarly, a study on MERS-CoV infection in pregnancy also has shown severe adverse outcomes, like preterm delivery, maternal respiratory failure, and neonatal intensive care unit (NICU) admission ${ }^{5}$. The novel Coronavirus (COVID-19), which comes from the same family viruses, can potentially cause adverse prenatal and neonatal outcomes. Emergent viral infections like, Zika virus, Ebola virus, and Marburg virus can infect fetus through vertical transmission and develops the complication in both mother and fetus ${ }^{6-8}$.

The lancet study conducted by Huang et al reported epidemiological, clinical, laboratory, radiological features and treatment outcomes of patients infected with novel Coronavirus (COVID-19) in Wuhan, China ${ }^{9}$. This study was only focused in non-pregnant adults. The physiological and immunocompromised changes in pregnancy can increase the susceptibility of pregnant women towards COVID-19 infection ${ }^{10}$. Currently, the evidence linked to clinical features, laboratory tests, neonatal outcomes, vertical transmission, and intrapartum care in pregnancy caused by COVID 19 is scarce. As COVID-19 is rapidly spreading, it is not only a public health issue, it is also very important to develop an obstetrical management plan to provide care for pregnant women. This systematic review is aimed to collect all studies related to COVID-19 positive pregnancy and summarize the symptoms, laboratory findings, treatment options, obstetric and neonatal outcomes. This will generate a pool of evidence for healthcare professionals to care for pregnant women and newborns.

\section{Materials and methods}

A systematic review was conducted according to the preferred reporting items for systematic review and metaanalysis (PRISMA) consensus statement ${ }^{11}$. All available and relevant studies on novel Coronavirus (COVID-19) infection among pregnant women were included in this review.

Study selection criteria: All studies relevant to COVID19 infection among pregnant women, and reported symptoms, laboratory findings, maternal characteristics, and neonatal outcomes. All studies which meet the above mentioned criteria, irrespective of design, and published in the English language are considered for inclusion. Review papers and studies not given any clear information about symptoms, laboratory findings, treatment, and maternal or neonatal outcomes are excluded from the review.

Search strategy: A systematic search was performed in PubMed, Scopus, Web of Science, and Cochrane databases on April 3, 2020. All studies published on from the start of COVID 19 were considered for inclusion. The collected studies were screened for COVID-19 among pregnant women and included in the study as per study criteria. Searching was made by combining text words and medical subject headings $(\mathrm{MeSH})$ by using Boolean words OR, AND, NOT in title/abstract.

Data extraction and analysis: Two authors extracted the data by using pre-designed, piloted, and customized data extraction form. The data extraction form consists of clinical features, laboratory findings, treatment, and perinatal outcomes. The corresponding author solved any disagreement in the data extraction. The modified Newcastle-Ottawa scale was used to assess the quality of included studies. Descriptive statistics were used to represent the data.

\section{Results and observations}

Study selection: A total of 2579 articles were identified by searching databases and other sources. In these articles, 21 duplicated, 1103 published prior COVID-19 incident, and 1706 not matched the abstract and title were excluded from the review. A total of 149 full text articles are selected for study eligibility screening, of which 125 articles were related to non-pregnant women, 8 articles are having different outcomes, 2 comprises wrong study design, and 2 published in other languages are subjected for exclusion. Finally, 12 articles were included in the study. The complete study selection criteria were given in the PRISMA flowchart figure 1 .

The background details of the included studies were summarized in table 1 . In total 12 studies, cross-sectional studies (2), case reports (2), case series (2), retrospective study (5), and case-control (1), study designs are present in the review. A total of 123 pregnant women included in the selected 12 articles, and the majority of them were in the third trimester.

Clinical manifestations of COVID 19 infected pregnant women: Fever $(60.2 \%)$ and cough $(36.6 \%)$ are the most 
The New Indian Journal of OBGYN. 2021 (July-December);8(1)

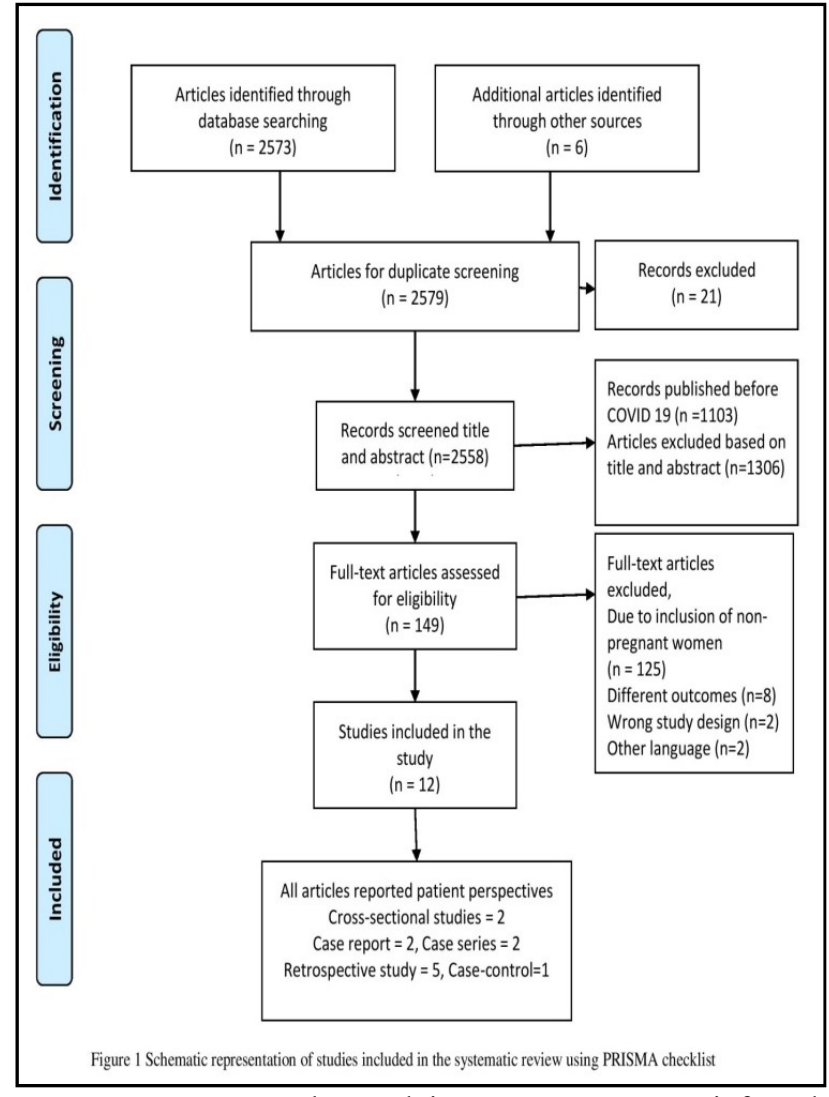

common symptoms observed in pregnant women infected with COVID 19. Some of the other and less common raised AST or ALT (21.0\%), lymphopenia (51.6\%), elevated C-reactive protein $(62.2 \%)$, and abnormal chest CT scan $(90.2 \%)$. Even though these tests are non-specific to the COVID-19, these tests are useful to monitor the prognosis of the infection towards treatment. Maternal rt-PCR for SARS $\mathrm{CoV}-2$ was positive in all pregnant women as shown in table 3 .

Treatment of COVID 19 infected pregnant women: Oxygen administration, antibiotic, and antiviral therapy is the mainstay of management strategy in the majority of the studies as shown in table 3. Antiviral drugs like arbidol, oseltamivir, lopinavir, ritonavir, ganciclovir, interferon was given in the study of Wang et al, Zhu at al, and Yu et al. Antibiotics like; cefoperazone sodium, cephalosporins, quinolones, macrolides, sulbactam sodium are given in the study of Wang et al and Zhu at al. Even though corticosteroid therapy is important to control SARS, due to secondary complication in the pregnant women, majority of studies not advised steroids in pregnant women. In this review, Fan et al study had given methylprednisolone given in (20mg. IV daily) within 72 hours of delivery.

Perinatal outcomes of pregnant women infected with COVID 19: The most common perinatal outcome observed in the COVID 19 pregnancy was, fetal distress (15.5\%) and low birth weight $(14.4 \%)$, followed by preterm delivery (13.4), neonatal dyspnea (7.3\%), bacterial pneumonia (2.4), neonatal death (2.24\%) and neonatal rt-PCR for SARS-

\begin{tabular}{|c|c|c|c|c|c|c|}
\hline Authors & $\begin{array}{l}\text { Study } \\
\text { design }\end{array}$ & $\begin{array}{l}\text { Study } \\
\text { location }\end{array}$ & $\begin{array}{l}\text { Study } \\
\text { date }\end{array}$ & $\begin{array}{l}\text { Sample } \\
\text { size }\end{array}$ & $\begin{array}{l}\text { Maternal age in } \\
\text { years(Mean } \pm S D)\end{array}$ & $\begin{array}{l}\text { Gestational age in week at } \\
\text { admission (Mean } \pm \text { SD) }\end{array}$ \\
\hline Chen et $\mathrm{al}^{27}$ & Retrospective cohort & Wuhan, China & 12 Feb, 2020 & 9 & $29.8 \pm 4.8$ & $37.1 \pm 1.2$ \\
\hline Liu et al ${ }^{28}$ & Case series & Wuhan, China & 25 Feb, 2020 & 3 & $32.7 \pm 2.3$ & $39 \pm 1$ \\
\hline Zhu et al ${ }^{20}$ & Retrospective cohort & Hubei, China & 10 Feb 2020 & 9 & $30.9 \pm 3.2$ & $35.4 \pm 2.9$ \\
\hline Wang et al $^{19}$ & Case report & Suzhou, China & 28 Feb, 2020 & 1 & 35 years & 31 Weeks \\
\hline Liu et al ${ }^{29}$ & Cross-sectional & Hubei, China & 11 Mar, 2020 & 41 & $31.0 \pm 5.0$ & NA \\
\hline Liu et $\mathrm{al}^{26}$ & Cross-sectional & Hubei, China & 7 March, 2020 & 15 & $32 \pm 5.0$ & $32 \pm 8$ \\
\hline Yu et $\mathrm{al}^{21}$ & Retrospective cohort & Wuhan, China & 24 Mar, 2020 & 7 & $32.2 \pm 2.1$ & $38.7 \pm 1.4$ \\
\hline Chen et $\mathrm{al}^{30}$ & Retrospective cohort & Hubei, China & 16 Mar, 2020 & 4 & $26.5 \pm 5.8$ & $37.7 \pm 0.9$ \\
\hline Khan et $\mathrm{al}^{31}$ & Case series & Wuhan, China & 19, Mar, 2020 & 3 & $29.3 \pm 3.2$ & $37 \pm 2.6$ \\
\hline Liu et $\mathrm{al}^{32}$ & Retrospective cohort & Hubei, China & 27, Feb. 2020 & 13 & $29.7 \pm 4.0$ & $33.8 \pm 3.9$ \\
\hline Fan et $\mathrm{al}^{34}$ & Case reports & Wuhan, China & 17, Mar, 2020 & 2 & $34 \& 29$ years & $37 \& 36$ Weeks \\
\hline Li et $\mathrm{al}^{33}$ & Case control & Wuhan, China & 30, Mar, 2020 & 16 & $30.9 \pm 3.2$ & $38 \pm 0.2$ \\
\hline
\end{tabular}

symptoms are also reported by the women; postpartum fever CoV2 (1.2\%). In a study conducted by Liu et al one death $(23.5 \%)$, dyspnea $(9.7 \%)$, fatigue $(12.2 \%)$, diarrhea $(4.1 \%)$, myalgia $(4.9 \%)$, sore throat $(4.1 \%)$, poor appetite $(2.4 \%)$, headache $(1.6 \%)$, malaise $(1.6 \%)$, and skin rash $(0.1 \%)$ as shown in table 2.

Laboratory findings of COVID 19 infected pregnant women: The most common abnormal laboratory finding observed in COVID 19 infected pregnant women include; was reported due to multiple organ dysfunction syndrome and stillbirth, whereas in Zhu et al study one more death was reported due to multiple organ failure, shock, gastric bleeding. The majority of the pregnant women delivered in the mode of $\mathrm{C}$-section, and very few are normal delivery mode. According to the Apgar score, all babies were normal; there was no distress at one and five minute points. Other 
Table 2: Symptoms of pregnant women infected with COVID-19 $(\mathrm{n}=123)$

\begin{tabular}{ll}
\hline Symptoms & No. (\%) \\
\hline Fever & $74(60.2)$ \\
Postpartum fever & $29(23.5)$ \\
Cough & $45(36.6)$ \\
Myalgia & $6(4.9)$ \\
Sore throat & $5(4.1)$ \\
Malaise & $2(1.6)$ \\
Diarrhea & $5(4.1)$ \\
Dyspnea & $12(9.7)$ \\
Fatigue & $15(12.2)$ \\
Headache & $2(1.6)$ \\
Poor appetite & $3(2.4)$ \\
Skin rash & $1(0.1)$ \\
\hline
\end{tabular}

studies and reviews of COVID-19 in normal adults and children ${ }^{13,14}$.

Up to the present day, there was no specific treatment or prevention strategy to deal with COVID-19 infection in all groups of the population. As we know that, pregnant women are at high risk for adverse effects of the drugs, put healthcare providers in an additional challenge. The currently available off labeled chloroquine and hydroxy chloroquine use in COVID-19 are a risk to the fetus ${ }^{15,16}$. Even these drugs can excrete through breast milk and increases the risk of adverse effects in infants 17,18 . Supportive and symptomatic therapy is very important in

Table 3: Laboratory findings and treatment of COIVD-19 infected pregnant women

\begin{tabular}{|c|c|c|c|}
\hline Laboratory finding & Studies mentioned test and treatment findings & $\begin{array}{l}\text { Sample } \\
\text { size }\end{array}$ & No $(\%)$ \\
\hline $\begin{array}{l}\text { Elevated C-reactive } \\
\text { protein }(>10 \mathrm{mg} / \mathrm{L})\end{array}$ & Chen et $\mathrm{al}^{27}$, Liu et $\mathrm{al}^{28}$, Liu et $\mathrm{al}^{29}$, Liu et $\mathrm{al}^{26}, \mathrm{Yu}$ et $\mathrm{al}^{21}$, Chen et $\mathrm{al}^{30}, \mathrm{Khan}_{\mathrm{et}} \mathrm{l}^{31}, \mathrm{Li}$ et $\mathrm{al}^{33}$ & 98 & $61(62.2)$ \\
\hline Lymphopenia & Chen et $\mathrm{al}^{27}$, Liu et $\mathrm{al}^{28}$, Liu et $\mathrm{al}^{29}$, Liu et $\mathrm{al}^{26}$, Chen et $\mathrm{al}^{30}$, Khan et $\mathrm{al}^{31}$, Fan et $\mathrm{al}^{34}$, Li et $\mathrm{al}^{33}$ & 93 & $48(51.6)$ \\
\hline Abnormal chest $\mathrm{CT}$ & All studies & 123 & $111(90.2)$ \\
\hline $\begin{array}{l}\text { Maternal rt-PCR for } \\
\text { SARS-CoV-2 }\end{array}$ & All studies & 123 & $123(100)$ \\
\hline \multicolumn{4}{|l|}{ Treatment } \\
\hline Oxygen therapy & 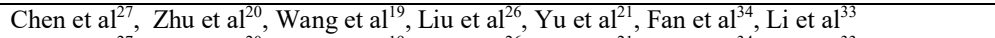 & 59 & $35(51.3)$ \\
\hline Antibiotic & $\mathrm{Chen} \mathrm{al}^{27}$, Zhu et $\mathrm{al}^{20}$, Wang et $\mathrm{al}^{19}$, Liu et $\mathrm{al}^{26}$, Yu et $\mathrm{al}^{21}$, Fan et $\mathrm{al}^{34}$, Li et $\mathrm{al}^{33}$ & 59 & $48(81.3)$ \\
\hline Antiviral & $\mathrm{Chen} \mathrm{al}^{27}$, Zhu et $\mathrm{al}^{20}$, Wang et $\mathrm{al}^{19}$, Liu et $\mathrm{al}^{26}$, Yu et $\mathrm{al}^{21}$, Fan et $\mathrm{al}^{34}$, Li et $\mathrm{al}^{33}$ & 59 & $33(55.9)$ \\
\hline Corticosteroid & 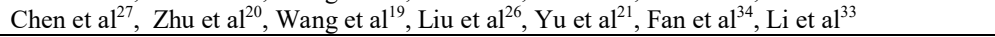 & 59 & $2(3.4)$ \\
\hline
\end{tabular}

outcomes like, diffuse scattered rashes, edema, facial skin lesion, late gestational age, and disseminated intravascular coagulation was also observed in the study conducted by Zhu et al. The perinatal outcome profile was represented in table 4 .

\section{Discussion}

The symptoms observed in the pregnant women were slightly different from the findings of the lancet study conducted by Huang et al in non-pregnant. In both pregnant and non-pregnant adults, fever and cough is the most common symptom ${ }^{9}$. In this review, we observed postpartum fever, poor appetite, dyspnea, sore throat, myalgia, fatigue, and malaise as additional symptoms. So, close monitoring of these symptoms will give a clue for the early detection of COVID 19. Similar types of symptoms are also observed in previous SARS-CoV in pregnancy ${ }^{12}$. This review supports abnormal chest CT scan, elevated C-reactive protein, and decline lymphocyte count are the major changes observed in COVID-19 infected pregnant women. Even though these tests are non-specific to the COVID-19, these tests are useful to monitor the prognosis of the infection towards treatment. These laboratory changes are also similar to the findings of pregnant women infected with COVID-19. Antiviral drugs like arbidol, oseltamivir, lopinavir, ritonavir, ganciclovir, interferon which were used for previous SARS in pregnancy can be recommended in COVID-19 ${ }^{19-21}$. There was no evidence available on the safety of these medicines in pregnancy conditions. Corticosteroid therapy is very important to control SARS, but due to secondary complications in pregnant women, majority of studies not advised steroids in pregnant women ${ }^{22}$. In this review, Fan et al study had given methylprednisolone given in $(20 \mathrm{~m}$. IV daily) within 72 hours of delivery in two patients. Antibiotics are recommended in the majority of the studies to treat secondary bacterial infections in COVID $19^{19,20}$.

According to $\mathrm{WHO}, 1-5 \%$ of $\mathrm{C}$-section is recommended to avoid death or severe morbidity in mother and newborn ${ }^{23}$, ${ }^{24}$. In the current review, we found that the majority $(77.3 \%)$ of pregnant women are delivered by $\mathrm{C}$-section. Evidence suggests that, in viral infection to reduce the adverse perinatal and neonatal outcomes C-section is strongly recommended ${ }^{25}$. Some other adverse obstetric and neonatal outcomes observed are preterm delivery, low birth weight, fetal distress, pre-rupture of the membrane. These outcomes 
The New Indian Journal of OBGYN. 2021 (July-December);8(1)

\begin{tabular}{|c|c|c|c|}
\hline Categories & Studies mentioned perinatal outcomes & $\begin{array}{c}\text { Sample } \\
\text { size }\end{array}$ & No (\%) \\
\hline Preterm delivery & 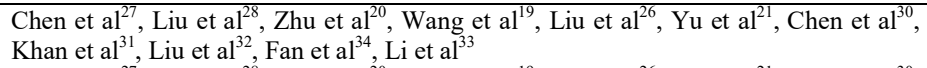 & 82 & $11(13.4)$ \\
\hline Prerupture of membrane & $\begin{array}{l}\text { Chen et } \mathrm{al}^{27} \text {, Liu et } \mathrm{al}^{28} \text {, Zhu et } \mathrm{al}^{20} \text {, Wang et } \mathrm{al}^{19} \text {, Liu et } \mathrm{al}^{26} \text {, Yu et } \mathrm{a}^{21} \text {, Chen et } \mathrm{al}^{30} \text {, } \\
\mathrm{Khan}_{\mathrm{a}} \mathrm{al}^{31} \text {, Liu et } \mathrm{al}^{32} \text {, Fan et } \mathrm{al}^{34} \text {, Li et } \mathrm{al}^{33}\end{array}$ & 82 & $3(3.6)$ \\
\hline Fetal distress & $\begin{array}{l}\text { Chen et } \mathrm{al}^{27} \text {, Liu et } \mathrm{al}^{28} \text {, Zhu et } \mathrm{al}^{20} \text {, Wang et } \mathrm{al}^{19} \text {, Liu et } \mathrm{al}^{26} \text {, Yu et } \mathrm{a}^{21} \text {, Chen et } \mathrm{al}^{30} \text {, } \\
\mathrm{Khan}^{3 \mathrm{a}^{31}} \text {, Liu et } \mathrm{l}^{32} \text {, Fan et } \mathrm{al}^{34} \text {, Li et } \mathrm{al}^{33}\end{array}$ & 82 & $13(15.8)$ \\
\hline Neonatal dyspnea & $\begin{array}{l}\text { Chen et } \mathrm{al}^{27} \text {, Liu et } \mathrm{al}^{28} \text {, Zhu et } \mathrm{al}^{20} \text {, Wang et } \mathrm{al}^{19} \text {, Liu et } \mathrm{al}^{26} \text {, Yu et } \mathrm{a}^{21} \text {, Chen et } \mathrm{al}^{30} \text {, } \\
\mathrm{Khan}_{\mathrm{a}} \mathrm{al}^{31} \text {, Liu et } \mathrm{l}^{32} \text {, Fan et } \mathrm{al}^{34} \text {, Li et } \mathrm{al}^{33}\end{array}$ & 82 & $6(7.3)$ \\
\hline Bacterial pneumonia & $\begin{array}{l}\text { Chen et } \mathrm{al}^{27} \text {, Liu et } \mathrm{al}^{28} \text {, Zhu et } \mathrm{al}^{20} \text {, Wang et } \mathrm{al}^{19} \text {, Liu et } \mathrm{al}^{26} \text {, Yu et } \mathrm{al}^{21} \text {, Chen et } \mathrm{al}^{30} \text {, } \\
\mathrm{Khan}^{3 \mathrm{a}^{31}} \text {, Liu et } \mathrm{al}^{32} \text {, Fan et } \mathrm{al}^{34} \text {, Li et } \mathrm{al}^{33}\end{array}$ & 82 & $2(2.4)$ \\
\hline C-section & $\begin{array}{l}\text { Chen et al } 27 \text {, Liu et } \mathrm{al}^{28} \text {, Zhu et } \mathrm{al}^{20} \text {, Wang et al }{ }^{19} \text {, Liu et } \mathrm{al}^{26} \text {, Chen et } \mathrm{a}^{30} \text {, Khan et } \mathrm{al}^{31} \text {, } \\
\text { Liu et } \mathrm{al}^{32} \text {, Fan et } \mathrm{al}^{34} \text {, Li et } \mathrm{al}^{33}\end{array}$ & 75 & $58(77.3)$ \\
\hline LBW & $\begin{array}{l}\text { Chen et } \mathrm{al}^{27} \text {, Liu et } \mathrm{al}^{28} \text {, Zhu et } \mathrm{al}^{20} \text {, Wang et } \mathrm{al}^{19} \text {, Liu et } \mathrm{al}^{26} \text {, Yu et } \mathrm{al}^{21} \text {, Chen et } \mathrm{al}^{30} \text {, } \\
\mathrm{Khan}^{3 \mathrm{l}^{13}} \text {, Fan et } \mathrm{al}^{34}, \text { Li et } \mathrm{al}^{33}\end{array}$ & 69 & $10(14.4)$ \\
\hline Apgar $1 \min (\geq 7)$ & 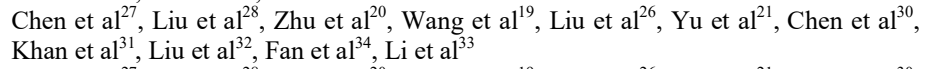 & 82 & $82(100)$ \\
\hline Apgar $5 \min (\geq 7)$ & 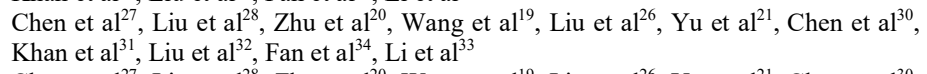 & 82 & $82(100)$ \\
\hline Neonatal death & $\begin{array}{l}\text { Chen et } \mathrm{al}^{27} \text {, Liu et } \mathrm{al}^{28} \text {, Zhu et } \mathrm{al}^{20} \text {, Wang et } \mathrm{al}^{19} \text {, Liu et } \mathrm{al}^{26} \text {, Yu et } \mathrm{al}^{21} \text {, Chen et } \mathrm{al}^{30} \text {, } \\
\mathrm{Khan}^{3 \mathrm{l}^{13}} \text {, Liu et } \mathrm{l}^{32} \text {, Fan et } \mathrm{al}^{34} \text {, Li et } \mathrm{al}^{33}\end{array}$ & 82 & $2(2.4)$ \\
\hline $\begin{array}{l}\text { Neonatal rt-PCR for SARS- } \\
\text { CoV-2 }\end{array}$ & 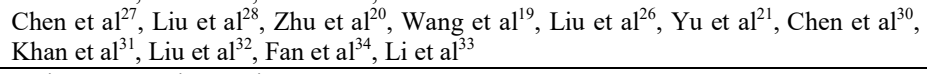 & 82 & $1(1.2)$ \\
\hline
\end{tabular}

alert healthcare workers in dealing and reducing perinatal from 10 studies, this is not a sufficient number to draw and neonatal complications of COVID-19.

Previous studies on SARS infection suggest that, high rate of vertical transmission of SARS infection from mother to fetus ${ }^{4,5}$. But, the scenario is completely contrasted in COVID-19, only one newborn got positive toward COVID19 infection; this happened after 36 hours of birth. The viral nucleic acid test of the placenta and cord blood was given negative for COVID-19. This suggests intrauterine vertical transmission has not occurred.

The previous studies on SARS infection confirmed that; the mortality rate is $10 \%$ in non-pregnant adults and $25 \%$ in pregnant women ${ }^{4}$. Current studies suggest that, the mortality rate of COVID 19 patients is $1-4 \%$. In the study conducted by Liu et al one death was reported due to multiple organ dysfunction syndrome and stillbirth, whereas in Zhu et al study one more death was reported due to multiple organ failure, shock, gastric bleeding ${ }^{20,26}$. Other outcomes like, diffuse scattered rashes, edema, facial skin lesion, late gestational age, and disseminated intravascular coagulation was also observed in the study conducted by Zhu et al. The maternal, obstetric, and neonatal outcomes of COVID 19 are better than the previous SARS infection.

Strengths and limitations: This is the prime review highlighting clinical, laboratory, maternal, obstetric, and neonatal outcomes of the COVID-19 infected pregnant women. These findings help healthcare professionals to promote better care in COVID-19 infected pregnant women. Even though the current review included 80 pregnant women conclusions and generalize the data, because all studies are from a single province China. In the current systematic review, there was no comparative, case-control or cohort study design to support the outcomes that occurred majorly due to COVID-19 and not due to other co-morbid conditions. The majority of the women in enrolled studies are in the third trimester, so, it will not give effects of COVID-19 infected women in the $2^{\text {nd }}$ and $1^{\text {st }}$ trimester. The long term effects of COVID 19 in pregnant women and neonates are not explained in this systematic review.

\section{Conclusions}

The study confirms that, fever, cough, elevated Creactive protein, lymphopenia, and abnormal chest $\mathrm{CT}$ are the most common clinical and laboratory examinations in pregnant women infected with COVID-19. The chloroquine and hydroxy chloroquine should not indicate in the treatment of COVID-19 in pregnant women because of the potential adverse effects on mother and fetus. Supportive therapy with oxygen, and antibiotics, and specific treatment with antiviral agents can be given but the safety profile of antiviral drug use was not established. COVID 19 increases the risk of Csection, preterm delivery, and low birth weight outcomes. All healthcare professionals need to consider possible outcomes in this review and make a decision to reduce the risk of complications in both mother and fetus. In the future, there is a need for inventions in the treatment and prevention of COVID 19 in the general population and pregnant women. 
Conflict of interest: None. Disclaimer: Nil.

\section{References}

1. Lu H, Stratton CW, Tang Y. Outbreak of pneumonia of unknown etiology in Wuhan, China: The mystery and the miracle. J Med Virol. 2020; 92(4):401-2.

2. Hui DS, I Azhar E, Madani TA, Ntoumi F, Kock R, Dar $\mathrm{O}$, et al. The continuing $2019-\mathrm{nCoV}$ epidemic threat of novel coronaviruses to global health - The latest 2019 novel coronavirus outbreak in Wuhan, China. Int $\mathrm{J}$ Infect Dis. 2020; 91: 264-6.

3. CDC. Coronavirus Disease 2019 (COVID-19) [Internet]. Centers for Disease Control and Prevention2020 [cited 2020 Apr 1]; Available from: https://www.cdc.gov/coronavirus/2019ncov/hcp/pregnant-women-faq.html

4. Wong SF, Chow KM, Leung TN, Ng WF, Ng TK, Shek $\mathrm{CC}$, et al. Pregnancy and perinatal outcomes of women with severe acute respiratory syndrome. Am J Obstet Gynecol. 2004;191(1): 292-7.

5. Alfaraj SH, Al-Tawfiq JA, Memish ZA. Middle East Respiratory Syndrome Coronavirus (MERS-CoV) infection during pregnancy: Report of two cases \& review of the literature. J Microbiol Immunol Infect. 2019; 52(3): 501-3.

6. Schwartz DA. Maternal Filovirus Infection and Death from Marburg and Ravn Viruses: Highly Lethal to Pregnant Women and Their Fetuses Similar to Ebola Virus [Internet]. In: Ikwaras Okware S, editor. Emerging Challenges in Filovirus Infections. Intech Open; 2020 [cited 2020 Apr 6]. Available from: https://www. intechopen.com/books/emerging-challenges-in-filovirusinfections/ maternal-filovirus-infection-and-death-frommarburg-and-ravn-viruses-highly-lethal-to-pregnantwomen

7. Alvarado MG, Schwartz DA. Zika Virus Infection in Pregnancy, Microcephaly, and Maternal and Fetal Health: What We Think, What We Know, and What We Think We Know. Archives of Pathology \& Laboratory Medicine. 2017;141(1): 26-32.

8. Schwartz DA. Maternal and Infant Death and the rVSVZEBOV Vaccine Through Three Recent Ebola Virus Epidemics-West Africa, DRC Équateur and DRC Kivu: 4 Years of Excluding Pregnant and Lactating Women and Their Infants from Immunization. Curr Trop Med Rep. 2019; 6(4): 213-22.

9. Huang C, Wang Y, Li X, Ren L, Zhao J, Hu Y, et al. Clinical features of patients infected with 2019 novel coronavirus in Wuhan, China. The Lancet. 2020; 395(10223): 497-506.

10. Rasmussen SA, Jamieson DJ, Uyeki TM. Effects of influenza on pregnant women and infants. American Journal of Obstetrics and Gynecology. 2012; 207(3): S3-8.

11. Moher D, Liberati A, Tetzlaff J, Altman DG, The PRISMA Group. Preferred Reporting Items for Systematic Reviews and Meta-Analyses: The PRISMA Statement. PLoS Med. 2009; 6(7): e1000097.

12. Lam CM, Wong SF, Leung TN, Chow KM, Yu WC, Wong TY, et al. A case-controlled study comparing clinical course and outcomes of pregnant and nonpregnant women with severe acute respiratory syndrome. BJOG. 2004;111(8): 771-4.

13. Song F, Shi N, Shan F, Zhang Z, Shen J, Lu H, et al. Emerging 2019 Novel Coronavirus (2019-nCoV) Pneumonia. Radiology. 2020; 295(1): 210-7.

14. Jiang F, Deng L, Zhang L, Cai Y, Cheung CW, Xia Z. Review of the Clinical Characteristics of Coronavirus Disease 2019 (COVID-19). J Gen Intern Med. 2020; 35(5):1545-9.

15. Gautret P, Lagier J-C, Parola P, Hoang VT, Meddeb L, Mailhe $\mathrm{M}$, et al. Hydroxychloroquine and azithromycin as a treatment of COVID-19: results of an open-label non-randomized clinical trial. International Journal of Antimicrobial Agents. 2020; 56(1):105949.

16. Levy M, Buskila D, Gladman DD, Urowitz MB, Koren G. Pregnancy outcome following first trimester exposure to chloroquine. Am J Perinatol. 1991; 8(3):174-8.

17. Saito M, Gilder ME, McGready R, Nosten $F$. Antimalarial drugs for treating and preventing malaria in pregnant and lactating women. Expert Opinion on Drug Safety. 2018; 17(11):1129-44.

18. American Academy of Pediatrics Committee on Drugs. Transfer of drugs and other chemicals into human milk. Pediatrics. 2001;108(3): 776-89.

19. Wang X, Zhou Z, Zhang J, Zhu F, Tang Y, Shen X. A case of 2019 Novel Coronavirus in a pregnant woman with preterm delivery. Clinical Infectious Diseases. 2020; 71(15): 844-6.

20. Zhu H, Wang L, Fang C, Peng S, Zhang L, Chang G, et al. Clinical analysis of 10 neonates born to mothers with 
The New Indian Journal of OBGYN. 2021 (July-December);8(1)

2019-nCoV pneumonia. Transl Pediatr. 2020; 9(1): 51- 60.

21. Yu N, Li W, Kang Q, Xiong Z, Wang S, Lin X, et al. Clinical features and obstetric and neonatal outcomes of pregnant patients with COVID-19 in Wuhan, China: a retrospective, single-centre, descriptive study. The Lancet Infectious Diseases. 2020; 20(5): P559-64.

22. Bandoli G, Palmsten K, Forbess Smith CJ, Chambers CD. A Review of Systemic Corticosteroid Use in Pregnancy and the Risk of Select Pregnancy and Birth Outcomes. Rheum Dis Clin North Am. 2017; 43(3): 489-502.

23. De Brouwere V, Dubourg D, Richard F, Van Lerberghe W. Need for caesarean sections in west Africa. Lancet. 2002; 359(9310): 974-5.

24. Khan MdN, Islam MM, Shariff AA, Alam MdM, Rahman MdM. Socio-demographic predictors and average annual rates of caesarean section in Bangladesh between 2004 and 2014. PLoS ONE. 2017; 12(5): e0177579.

25. Sharma D, Spearman P. The impact of cesarean delivery on transmission of infectious agents to the neonate. Clin Perinatol. 2008; 35(2): 407-20.

26. Liu D, Li L, Wu X, Zheng D, Wang J, Yang L, et al. Pregnancy and Perinatal Outcomes of Women With Coronavirus Disease (COVID-19) Pneumonia: A Preliminary Analysis. American Journal of Roentgenology. 2020; 215(1):1-6.

27. Chen H, Guo J, Wang C, Luo F, Yu X, Zhang W, et al. Clinical characteristics and intrauterine vertical transmission potential of COVID-19 infection in nine pregnant women: a retrospective review of medical records. The Lancet. 2020; 395(10226): 809-15.

28. Liu W, Wang Q, Zhang Q, Chen L, Chen J, Zhang B, et al. Coronavirus Disease 2019 (COVID-19) During Pregnancy: A Case Series. 2020 [cited 2020 Apr 6]; Available from: https:// www. preprints.org/ manuscript/ 202002.0373/v1

29. Liu H, Liu F, Li J, Zhang T, Wang D, Lan W. Clinical and CT imaging features of the COVID-19 pneumonia:
Focus on pregnant women and children. Journal of Infection. 2020; 80(5):e7-e13.

30. Chen Y, Peng H, Wang L, Zhao Y, Zeng L, Gao H, et al. Infants Born to Mothers With a New Coronavirus (COVID-19). Front Pediatr. 2020; 8:104.

31. Khan S, Peng L, Siddique R, Nabi G, Nawsherwan, Xue $\mathrm{M}$, et al. Impact of COVID-19 infection on pregnancy outcomes and the risk of maternal-to-neonatal intrapartum transmission of COVID-19 during natural birth. Infect Control Hosp Epidemiol. 2020;1-9.

32. Liu Y, Chen H, Tang K, Guo Y. Clinical manifestations and outcome of SARS-CoV-2 infection during pregnancy. J Infect. 2020. doi: 10.1016/j.jinf. 2020. 02.028 [Epub ahead of print].

33. Li N, Han L, Peng M, Lv Y, Ouyang Y, Liu K, et al. Maternal and neonatal outcomes of pregnant women with COVID-19 pneumonia: a case-control study. Clinical Infectious Diseases. 2020; 71(16):2035-41.

34. Fan C, Lei D, Fang C, Li C, Wang M, Liu Y, et al. Perinatal Transmission of COVID-19 Associated SARSCoV-2: Should We Worry? Clin Infect Dis. 2020; 72(5): $862-4$.

\footnotetext{
Swat Narayana Goruntla ${ }^{1}$, Jyothi Suchitra ${ }^{2}$, Kannan M Shanmugha ${ }^{3}$, Dasaratharamaiah Jinka ${ }^{4}$, Mohammad Jaffar Sadiq ${ }^{5}$, Vigneshwaran Easwaran ${ }^{6}$

${ }^{1}$ Associate Professor, Department of Pharmacy Practice, Raghavendra Institute of Pharmaceutical Education and Research (RIPER) - Autonomous, Anantapur, Andhra Pradesh, India; ${ }^{2}$ Head, Department of Obstetrics and Gynaecology, Rural Development Trust Hospital, Bathalapalli, Andhra Pradesh, India; ${ }^{3}$ Department of Anaesthesiology, Rural Development Trust Hospital, Bathalapalli, Andhra Pradesh, India; ${ }^{4}$ Head, Department of Pediatrics, Rural Development Trust Hospital, Bathalapalli, Andhra Pradesh, India; ${ }^{5}$ Assistant Professor, Department of Clinical Pharmacology, Batterjee Medical College, Jeddah 21442, Kingdom of Saudi Arabia; ${ }^{6}$ Assistant Professor, Clinical Pharmacy Department, College of Pharmacy, King Khalid University, Abha, Saudi Arabia.
} 